\title{
Factors Affecting Technology Adoption in Small Community Farmers in Relation to Reproductive Events in Tropical Cattle Raised under Dual Purpose Systems
}

\author{
C. S. Galina1, F. Turnbull2 ${ }^{2}$ A. Noguez-Ortiz ${ }^{2}$ \\ ${ }^{1}$ Departamento de Reproducción, Facultad de Medicina Veterinaria y Zootecnia, Universidad Nacional \\ Autónoma de México, México DF, México \\ ${ }^{2}$ Departamento de Información y Servicios Documentales, Dirección General de Bibliotecas Universidad \\ Nacional Autónoma de México, México DF, México \\ Email: alu.mlvz@gmail.com
}

Received 20 November 2015; accepted 23 January 2016; published 26 January 2016

Copyright $\odot 2016$ by authors and Scientific Research Publishing Inc.

This work is licensed under the Creative Commons Attribution International License (CC BY). http://creativecommons.org/licenses/by/4.0/

(c) (i) Open Access

\section{Abstract}

The impact of technology adoption among farmers in developing countries has been an issue difficult to measure and interpret. Hence, research to improve production has been centered in technology that possible is not adequate for this region. The present review aims to utilize subjects such as Genetics, Reproduction, Nutrition, Management and Animal Health as examples of research endeavors illustrating the scarcely bond existing between research and adoption of technology. A final section is an attempt to illustrate the possible reasons why the transfer of technology is failing to be of any consequence at least under the conditions of developing countries.

\section{Keywords}

Tropics, Artificial Insemination, Embryo Transfer, Nutritional Supplementation

\section{Introduction}

The production of beef and milk in the majority of countries in the tropics has been transformed through time into more intensive systems with a high concentration of animals in smaller areas. However, in spite of this tendency, the traditional systems for dual purpose continue to be the principal subsistence for numerous families 
even though they lack infrastructure and sound production. Nonetheless, these systems yield about $41 \%$ of the total milk and $50 \%$ of beef for the area [1].

There are numerous and diverse systems of production in the tropics but a common bond in all of them is the purchasing power and economic ability of the producer to invest in the enterprise. Based on these premises, researchers have arbitrarily divided farmers in subsistence, medium income and those with sound budgets. The shortcomings and virtues of these divisions will be discussed. Adoption of technology has to be closely connected to the economic stability of the farmer. Success in the enterprises with limited budgets was related in the past to government or international initiatives based on subsidies, when this support ensued, farmers were left with scarce possibilities to implement the recommended strategies.

The present review aims to highlight some productive events in the farm as examples of past and current technology and the pitfalls to absorb and implement these techniques, and moreover, to illustrate the little impact of experimental research in tropical animal production.

\section{Genetic Programs}

Producers have based their efforts on an indiscriminative crossing of diverse breeds, ending up with animals characterized without a defined phenotype or production performance. These cattle are hardy, resistant to the environment but with a limited ability to produce either beef or milk [2]. Other researchers, particularly in Latin America have attempted to reincorporate the native breeds brought by the Spaniards before the XIX century, to improve production to the already existing systems. There are quite a number of papers concerning the rescue of native breeds (either Bos taurus or Bos indicus). However, generally based on the numbers of animals of any particular breed, it seems to be that this technology has not been properly adopted in the tropics.

Innumerable efforts have been vested to import specialized European breeds such as the Holstein Friesian, Jersey or Brown Swiss to the area, more failures than success stories have been accounted for in the literature, probably due to the low adaptation of these animals to the harsh environmental conditions in the tropics [3].

Finally, in the 90's considerable interest was given to a more selective program based on the crossbreeding of European breeds with Bos indicus types, in effect, assays comparing purebred animals with F1 or other levels of crossing have concluded that the F1 animal is by far the best choice for meat or milk production [4]. Thus, the hybrid vigor product of crossing two purebreds proved to be an incentive for farmers [5]. Even more, researchers experimented alternative crossing of two breeds to ended up in the production of synthetic breeds (the majority 5/8 of one bred and 3/8 of the other) such as the Cuban Syboney, Australian Milking Zebu or Jamaican Hope to cite a few. It is beyond the scope of this review to describe the advantages and disadvantages of the different combinations experimented in the 90's. However, it gives the impression to be an agreement that these systems are not applicable in small community enterprises as the volume of animals is limited; hence it is not feasible to implement an alternative crossbreeding program. To conclude, evidence points out that if the animal has more than $75 \%$ of European genes, the adaptation to the local environment is hazardous; on the other hand if the animal possesses $75 \%$ of zebu genes, then expression of production indicators are very limited.

Recently [6], evaluated the feasibility of using embryo transfer in F1 crossbred animals (Holstein $\times$ Indobrasil) placing an F1 embryo in the undefined animal hence avoiding long periods of crossbreeding and favoring the hybrid vigor enhancing the production of either beef or milk. The economic calculations of these authors for the moment make this approach not a valuable strategy in small community farmers [7] [8]. This is probably why most of the reviews on embryo transfer are of experiences obtained in the use of the technique in Bos taurus animals [9]. Nonetheless, recent evidence from Brazil has shown promising results in Bos indicus cattle using embryo transfer in large herds [10].

\section{Reproduction}

Traditionally, farmers have used natural mating (NM) as the most advantageous procedure to reproduce their animals. Unfortunately, the genetic progress encountered through this system is minimal and for this reason, government policies have been geared towards using artificial insemination (AI) as a vehicle to introduce new and improved breeds in the tropics [6]. The adoption of this technology is somewhat dissimilar. Progressive farmers have found that the system can be economically sound if investment in training of personnel directly involved in the implementation of the technique is applied. This investment is geared towards solving problems 
such as inefficient estrus detection and poor fertility following AI. With the advent of pharmacological procedures to manipulate the estrous cycle [11] it is possible to a certain degree to eliminate the problem of estrus detection [12]. The economic feasibility of these procedures remain to be tested as the physiological state of the animals (anestric, with a calf suckling or poor nutrition) affects the capacity of producers to implement AI [13]. In effect Alonso et al., [14] found in an experiment where cows were AI by appointment but observed continuously for $100 \mathrm{~h}$ following synchronization that $85 \%$ of the animals displaying estrus ovulated, contrasting with only $63 \%$ that did not. Fertility in the whole herd was $25 \%$; however, $86 \%$ of these pregnancies were detected in animals that displayed estrus.

In essence, it is relatively easier to have the bull running with the cows at all times [15] hence reducing the human error consequence of poor estrous detection efficacy and precision, or mistakes in the technique itself (poor implementation of thawing procedures, inaccurate placing of the semen in the body of the uterus and inefficient storage in the liquid nitrogen container to mentioned just a few [16]. How much extension services would recommend the use of AI among small producers is a debatable issue that deserves further investigation. For example, there are several procedures to facilitate the milk let down of the cows, starting from the suckling of the calf and a prompt removal after milk flow, or allowing the calf to suckle one teat after milking or giving the feed to the calf from a pool of residual milk [17] [18]. What effect those any of these systems bear on the onset of ovarian activity?? How these methods affect the performance of the calf?? All these interventions deserve further research to recommend one over the other.

\section{Feeding}

This procedure is possibly the major hurdle affecting production in the tropics. As most systems are based on grazing as the main element for feeding, farmers face two very different scenarios for adopting an adequate procedure. During the dry season, fodder is scarce and of poor quality and in some countries, actually quite dramatic, especially nowadays with the constant climatic changes due to global warming. In contrast, during the rainy season, pasture seems to be available in quantity but pending on the conditions, probably with large concentrations of water. In spite of the fact that these events are well known, surprisingly there are very few sound strategies recommending the use of particular techniques to overcome these difficulties. In general it can be said that farmers should think that there is going to be little rain during the season so they should prevent for the possible draught. Unfortunately this is easier to recommend, not so to implement. Feeding procedures are certainly quite different between farmers with poor as opposed to sound budgets for investment. In general this is reflected in cow performance, particularly milk production. Animals properly fed, usually have productions above 8 lt per day; this is obviously closely related to the ability of the breed to adapt to the climatic conditions in the area and their capacity to dissipate heat [19]. Seasonal production of milk poses a serious problem in the commercialization of the product. At the moment, in the majority of tropical countries there is abundant production of milk in the rainy season (following a peak of calvings in the spring) and very little milk at the end of the rainy season. However, this statement deserves a qualification as there are specialized units in the tropics capable of producing milk the whole year around. Feeding strategies are mostly aimed to utilize local resources, the days of importing feedstuffs from more temperate areas (mostly grains with high energy and protein content) are likely over. A challenge to feed a balanced diet with scarce fodders rich in protein is a quest that specialists should have in their forefront of their research.

For example, Kamanzi, and Mapiye [20] in a study in Rwanda considered that land scarcity was ranked as the most important cause of feed shortage followed by inadequacy of forage planting material and lack of knowledge on forage production and utilization. To ensure sustainable viability of smallholder dairying in densely populated highlands, the following recommendations have been put forward: a) screening and evaluation of high-yielding and easily propagated pastures, b) incorporation of forages into cropping systems, c) value addition of low quality roughages and d) training farmers on forage production and utilization. The amount of milk produced will depend largely on two issues, the percentage of European genes that the animals have and the feeding regime imposed. However, it seems to be evidence in the literature [21] that the quantity so much as the quality of the food, determines milk production. If this statement is correct, would it be possible to implement a diet based on the ability of certain bacteria to synthesized fiber? Some studies [22] suggested that this is possible. The question still remains, are the animals existing today capable of a substantial improvement in milk production if the quality, quantity or both can be manipulated with local products??? 


\section{Management}

An interesting study was published [23], in dual crossbred cattle specialized in milk production, who found that if the animal had comfortable accommodation the key for calving was comfort, hence the spread of this event was in the cooler winter months. In contrast, cattle raised under primitive installations and poor management, the calving season was mostly concentrated in the summer when fodder was more abundant. Management plays a very important role in the fate of a production unit in the tropics; generally accommodations are rustic, fairly basic and old. Farmers have to deal with these types of facilities and this is not a small feat. Unfortunately, the investment required for improving their farms is quite considerable and not permissible under the prices currently found in the market for animal products. There is a need for a more serious and long term program from governments in developing countries to overcome this issue. The lack of an effort will translate in more migration from the countryside to the urban areas. The average age of a farmer in certain tropical areas is 55 years [24]. How long these systems will be sustainable if there is lack of incorporation of younger farmers?

For example, Hostiou et al., [25] found that most of the tasks (milking, grazing management) are performed manually. A study, based on the quantification of working time shows that most of the activities are carried out exclusively by family manpower; at times, helped by wage earners, volunteer workers and farmers' mutual aid. The study reveals the high variability of routine work (from 913 to 3955 hours per year for milk production) and seasonal work (from 17 to 328 days per season). Also, Lopez-Pereira [26] stated that the continuing soil erosion and land degradation in these low-input staple crop production hillside farming systems lead to be pessimistic about increasing the agricultural incomes of these farmers. However, this study shows that the appropriate combination of improved technologies and agricultural policy or alternative production diversification strategies, can advance the incomes of small-scale hillside farmers in by over $50 \%$. The technology components considered are stone walls and ditches combined with living tree barriers to prevent erosion of the hillsides, and a package of improved sorghum seed, and modest doses of nitrogenous fertilizer. The study concluded that erosion-control devices and yield-increasing crop varieties and fertilizers are effective technologies for the erosion-prone hillside landholdings found in many areas of the tropics. A similar strategy was undertaken years later [27] observing that by only using trees as shade from the blazing sun would improve the forage capacity of the pasture by preventing early desiccation and dryness of the fodder. Murgueitio et al., [28] proposes that extensive use of the land deeply rooted in the culture and rural economy of the region, requires an urgent transformation if it is to become both more efficient and environmentally friendly. Silvopastoral systems incorporating native trees and shrubs are instrumental for the productive rehabilitation of cattle production and for biodiversity conservation in agricultural landscapes

\section{Animal Health}

The welfare of the cow and the calf soon after calving is an event where little information has been afforded by researchers in the area. This is probably the consequence of a sequel of normal events during this stage. In effect, diseases such as retained placenta, hypocalcaemia or ketosis are rarely reported and it seems that calf survival is the major issue soon after calving. The majority of cows tend to calve outdoors hence predators are important. Health issues seem to be concentrated in the control of parasites both external and internal which undoubtedly affects animal performance. For example an interesting study was performed by reference [4], where different combinations of crossbred animals (Bos taurus $\times$ Bos indicus) were compared. The best performance and disease resistant was by far the F1 crossbred animal.

\section{Adoption of Technology}

Tey and Brindal [29], in a review concurred that adoption of technology is driven by factors such as, 1) socioeconomic, 2) agro-ecological, 3) institutional, 4) information, 5) farmer perception, 6) behavioral and 7) technological issues. Some of these relatively "fixed" factors are useful for market segmentation and targeting purposes. Other "modifiable" factors can be reshaped through interventions. On the other hand, reference [30] found significant correlation coefficients between and within farm household characteristics and technology adoption. For example, male-headed households adopted significantly a higher number of technologies than female-headed households. Technology adoption rates increased significantly with the stage of education and family size and decreasing distance from market or trade centers. The level of technology adoption by small- 
holder farmers is still unsatisfactory and is highly dependent on gender, family size, location and level of education [31]. The authors concluded that the geographical site where the farms were situated, the size of the farm and the level of education of the farmers were very important in the success of an enterprise. However, the frequency of the visits of the farm owners and technicians alike, were also major players to bring stability to the farm.

Bellows et al., [32] reported that the adoption of land and agrochemical-intensive methods by resource-poor farmers cultivating steep lands, resulted in decreased environmental and economic sustainability. Farmers with adequate resources were able to maintain viability by transferring land out of beans and into other commodities, particularly cattle. However, this shift in resource use affected social equity by decreasing farm labor opportunities for smallholders and landless farmers and diminishing land available for tenants. This study indicate that the impact of technology introduction on farming system sustainability can be assessed effectively by conducting integrated socioeconomic and agronomic analyses across farms representing various in land-use practices and intensities.

All these factors reported above are all important in decision making in the farm, but also in the researchers interpretation involving the magnitude of each factor in their recommendations to improve animal production in the tropics. The failure of many international and national programs has been the consequence of their inability to understand the local conditions thus applying a suitable program basically tailor made for the region in question. In fact, researchers in emerging countries should focus their efforts and resources in developing technologies based on the local conditions and needs of people, instead of investing them in studies which application is often expensive and unpractical.

In general there is agreement that there are mainly four different systems from transferring information to the farmer. Probably the most ancient one is related to the data generated in experimental stations or universities and transmitted to farmers in a variety of systems, either by technical bulletins, field days or conferences given by technicians in forums directed to farmers. The most obvious system, extension services to the farmer, is practically nonexistent in developing countries for lack of a budget to support this important department of diffusion of knowledge generated by the researchers in the experimental station. Moreover, the results obtained in the experimental stations are hardly reproduced by the local farmer for many reasons but probably the most important is the difficulty in transferring data from a controlled environment (such as the one in an experimental condition) to the farmers working with different infrastructure, economy and labor. The second in importance and gaining popularity in recent years, is the diffusion of data generated in the farm itself either by experiments carried out in situ, or by retrieving information that the farmer has documented in one way or another. This method has created the need for a more active institutional input to diffuse this knowledge. There are however, successful examples of this method. In Costa Rica a program started about 15 years ago to digitalize their information using software that could be implemented by the majority of farmers hence facilitating the diffusion of productive parameters via the network or having field days among the participating farmers. Similar examples are becoming more frequent in different parts of the developing world. The third system or method of transferring technology has been the support or government or international organizations in defined programs to improve the conditions of farmers' enterprises. Experience has shown that this type of effort is successful as long as the subsidy is present, once the program ended; farmers find it hard to accept that there is a valid need to invest in their farms. This is particularly so in the long term programs where results are not immediate and visible to the farmer.

\section{Conclusion}

Finally, a relatively untested system is the diffusion of information between farmers themselves, either by informal chatting or visits to other farms to learn something that they could implement in their farms. This system of diffusion of technology should be accurately measured to understand their dimensions.

\section{References}

[1] Gonzalez-Garcia, E., Gourdine, J.L., Alexandre, G., Archimede, H. and Vaarst, M. (2012) The Complex Nature of Mixed Farming Systems Requires Multidimensional Actions Supported by Integrative Research and Development Efforts. Animal, 6, 763-777. http://dx.doi.org/10.1017/S1751731111001923

[2] Aluja, A. and McDowell, R.E. (1984) Decision Making by Livestock/Crop Small Holders in the State of Veracruz, 
Mexico. Cornell International Agricultural Mimeograph, 105, 1-44.

[3] Vaccaro, R., Cardozo, R. and Vaccaro, L. (1983) Milk Production, Reproduction, and Death Rates of Holstein Heifers Imported into the Tropics. Tropical Animal Production, 8, 77-86.

[4] Madalena, F. (1993) A Simple Scheme to Utilize Heterosis in Tropical Dairy Cattle. World Animal Review, 74, 17-25.

[5] Cunningham, E.P. (1989) The Genetic-Improvement of Cattle in Developing-Countries. Theriogenology, 31, 17-28. http://dx.doi.org/10.1016/0093-691X(89)90557-8

[6] Alarcon, M.A., Galina, C.S., Corro, M.D. and Aspron, M.A. (2010) Embryo Transfer, a Useful Technique to Be Applied in Small Community Farms? Tropical Animal Health and Production, 42, 1135-1141. http://dx.doi.org/10.1007/s11250-010-9536-z

[7] Thibier, M., Humblot, P. and Guerin, B. (2004) Role of Reproductive Biotechnologies: Global Perspective, Current Methods and Success Rates. Farm Animals Genetic Resources, 30, 171-189.

[8] Sánchez, Z., Lammoglia, M., Alarcón, M., Romero, J. and Galina, C. (2015) Is the Production of Embryos in SmallScale Farming an Economically Feasible Enterprise? Reproduction in Domestic Animals, 50, 574-579. http://dx.doi.org/10.1111/rda.12526

[9] Hasler, J.F. (2003) The Current Status and Future of Commercial Embryo Transfer in Cattle. Animal Reproduction Science, 79, 245-264. http://dx.doi.org/10.1016/S0378-4320(03)00167-2

[10] Baruselli, P.S., Ferreira, R.M., Sa Filho, M.F., Nasser, L.F., Rodrigues, C.A. and Bo, G.A. (2010) Bovine Embryo Transfer Recipient Synchronisation and Management in Tropical Environments. Reproduction, Fertility and Development, 22, 67-74. http://dx.doi.org/10.1071/RD09214

[11] Bó, G.A., Baruselli, P.S. and Martinez, M.F. (2003) Pattern and Manipulation of Follicular Development in Bos indicus Cattle. Animal Reproduction Science, 78, 307-326. http://dx.doi.org/10.1016/S0378-4320(03)00097-6

[12] Baruselli, P.S., de Sa Filho, M.F., Martins, C.M., Nasser, L.F., Nogueira, M.F., Barros, C.M. and Bo, G.A. (2006) Superovulation and Embryo Transfer in Bos indicus Cattle. Theriogenology, 65, 77-88. http://dx.doi.org/10.1016/j.theriogenology.2005.10.006

[13] Roelofs, J., López-Gatius, F., Hunter, R.H.F., van Eerdenburg, F.J.C.M. and Hanzen, C. (2010) When Is a Cow in Estrus? Clinical and Practical Aspects. Theriogenology, 74, 327-344. http://dx.doi.org/10.1016/j.theriogenology.2010.02.016

[14] Alonso, L., Galina, C.S., Maquivar, M., Romero, J.J., Molina, I. and Carvajal, P. (2009) Fertility Assessment of Bos indicus Cows According to the Estrus Intensity, in a Fixed Time Artificial Insemination Program under Tropical Conditions. Revista Científica FCV-LUZ, 19, 639-644.

[15] Galina, C.S., Horn, M.M. and Molina, R. (2007) Reproductive Behaviour in Bulls Raised under Tropical and Subtropical Conditions. Hormones and Behavior, 52, 26-31. http://dx.doi.org/10.1016/j.yhbeh.2007.03.026

[16] Rhodes, F., Galina, C., Duchateau, A. and Soto, C. (1985) An Investigation into the Properties of Bovine Semen in the Mexican Tropics. World Review of Animal Production, 21, 15-19.

[17] Galina, C.S., Rubio, I., Basurto, H. and Orihuela, A. (2001) Consequences of Different Suckling Systems for Reproductive Activity and Productivity of Cattle in Tropical Conditions. Applied Animal Behaviour Science, 72, 255-262. http://dx.doi.org/10.1016/S0168-1591(01)00115-0

[18] Pérez-Torres, L., Orihuela, A., Corro, M., Rubio, I., Cohen, A. and Galina, C.S. (2014) Maternal Protective Behavior of Zebu Type Cattle and Its Association with Temperament. Journal of Animal Science, 92, 4694-4700. http://dx.doi.org/10.2527/jas.2013-7394

[19] De Rensis, F. and Scaramuzzi, R.J. (2003) Heat Stress and Seasonal Effects on Reproduction in the Dairy Cow-A Review. Theriogenology, 60, 1139-1151. http://dx.doi.org/10.1016/S0093-691X(03)00126-2

[20] Kamanzi, M. and Mapiye, C. (2012) Feed Inventory and Smallholder Farmers' Perceived Causes of Feed Shortage for Dairy Cattle in Gisagara District, Rwanda. Tropical Animal Health and Production, 44, 1459-1468. http://dx.doi.org/10.1007/s11250-012-0087-3

[21] Peña, C.R. (1993) Evaluación de fincas ganaderas del trópico con diferente nivel tecnológico en suplementación alimentaria, producción láctea, condición corporal y la relación de estas con la actividad ovárica postparto de vacas mestizas en época de secas. Universidad Nacional Autónoma de México, Facultad de Medicina Veterinaria y Zootecnia, México.

[22] Varga, G.A. and Kolver, E.S. (1997) Microbial and Animal Limitations to Fiber Digestion and Utilization. The Journal of Nutrition, 127, 819S-823S.

[23] Martínez, A., Galina, C., Basurto, H., Lamothe, C. and Aluja, A. (1988) Evaluacion de la actividad reproductiva en diferentes sistemas de produccion lechera en el municipio de Tlapacoyan, Veracruz, Mexico. Veterinaria México, 19, 295-299. 
[24] European Commission (2002) La mujer en la agricultura. Oficina de Publicaciones Oficiales de las Comunidades Europeas, Luxemburgo, 38.

[25] Hostiou, N., Tourrand, E.F., da Veiga, J.B., Alves, A.M.N. and Borbosa, T. (2006) The Tabour Organization of SmallScale Breeders in the Brazilian Amazon Is a Key Point for Sustainable Development. Changing European Farming Systems for a Better Future: New Visions for Rural Areas, 247-251.

[26] Lopez-Pereira, M.A., Sanders, J.H., Baker, T.G. and Preckel, P.V. (1994) Economics of Erosion-Control and SeedFertilizer Technologies for Hillside Farming in Honduras. Agricultural Economics, 11, 271-288. http://dx.doi.org/10.1016/0169-5150(94)00010-7

[27] Yamamoto, W., Dewi, I.A. and Ibrahim, M. (2007) Effects of Silvopastoral Areas on Milk Production at Dual-Purpose Cattle Farms at the Semi-Humid Old Agricultural Frontier in Central Nicaragua. Agricultural Systems, 94, 368-375. http://dx.doi.org/10.1016/j.agsy.2006.10.011

[28] Murgueitio, E., Calle, Z., Uribe, F., Calle, A. and Solorio, B. (2011) Native Trees and Shrubs for the Productive Rehabilitation of Tropical Cattle Ranching Lands. Forest Ecology and Management, 261, 1654-1663. http://dx.doi.org/10.1016/j.foreco.2010.09.027

[29] Tey, Y.S. and Brindal, M. (2012) Factors Influencing the Adoption of Precision Agricultural Technologies: A Review for Policy Implications. Precision Agriculture, 13, 713-730. http://dx.doi.org/10.1007/s11119-012-9273-6

[30] Mekonnen, H., Dehninet, G. and Kelay, B. (2010) Dairy Technology Adoption in Smallholder Farms in “Dejen” District, Ethiopia. Tropical Animal Health and Production, 42, 209-216. http://dx.doi.org/10.1007/s11250-009-9408-6

[31] Velasco-Fuenmayor, J., Ortega-Soto, L., Sanchez-Camarillo, E. and Urdaneta, F. (2009) Influence Factors on the Current Technological Level in the Dual-Purpose Cattle Farms Located in the State of Zulia, Venezuela. Revista Cientifica-Facultad de Ciencias Veterinarias, 19, 187-195.

[32] Bellows, B.C., Hildebrand, P.E. and Hubbell, D.H. (1996) Sustainability of Bean Production Systems on Steep Lands in Costa Rica. Agricultural Systems, 50, 391-410. http://dx.doi.org/10.1016/0308-521X(94)00069-4 